\title{
Thermal evaluation of a double glazing façade system with integrated Parallel Slat Transparent Insulation Material (PS-TIM)
}

\author{
Yanyi Sun, Yupeng Wu*, Robin Wilson and Shuyue Sun \\ Department of Architecture and Built Environment, Faculty of Engineering, The University of \\ Nottingham, University Park, Nottingham, NG7 2RD, UK \\ *Corresponding author: Tel: +44 (0) 11574 84011; emails: Yupeng.Wu@nottingham.ac.uk, \\ Jackwuyp@googlemail.com
}

\begin{abstract}
Concerns over sustainability in the built environment have resulted in continuous efforts to improve the performance of glazed façade systems and hence indoor comfort and building energy conservation. An innovative façade system where parallel transparent plastic slats are sandwiched between glass panes to form a Parallel Slat Transparent Insulation Material (PSTIM) is proposed as a strategy to effectively reduce coupled convective and radiative heat transfer between the panes of a double glazed window. This strategy increases the thermal resistance of the façade, while maintaining access to daylight. A numerical investigation of the thermal and optical performance of this façade system is presented. Detailed modelling of the thermal characteristics of a double glazed window containing PS-TIMs was carried out for different cell aspect ratios (defined by the thickness of window air cavity and slat interval distance), slat thickness and slat properties (conductivities and emissivities) using a validated Computational Fluid Dynamic (CFD) model. The CFD predictions show that: 1) an aspect ratio of 0.35 can provide full suppression of convection; 2) the PS-TIM structure can achieve a 35-46\% reduction in thermal conductance compared with the same double glazing in the absence of PS-TIM; 3) material conductivity, thickness and emissivity have a more apparent influence on small cell structures than large cell structures. In addition, a simple analysis of U-value and light transmittance at various solar incidence angles was undertaken. The results provide a better understanding of the benefits of PS-TIM in terms of energy saving and offer suggestions for the improved design of glazing façade systems.
\end{abstract}

Keywords: Parallel Slat Transparent Insulation Material (PS-TIM), Computational Fluid Dynamics (CFD), heat transfer, optical performance.

\section{NOMENCLATURE}




\section{Symbols}

$\begin{array}{cl}\text { A } & \text { aspect ratio A }=\mathrm{L} / \mathrm{s} \\ \mathrm{C}_{\mathrm{p}} & \text { specific heat capacity } \\ \text { Const. } & \text { constant } \\ \mathrm{d} & \text { thickness of glass pane } \\ \mathrm{D} & \text { distance between } \\ & \text { neighbouring slats or } \\ & \text { thickness of the slat } \\ \mathrm{e} & \text { exponent } \\ \mathrm{F} & \text { view factor } \\ \mathrm{g} & \text { gravitational acceleration } \\ \mathrm{h} & \text { heat transfer coefficient } \\ & - \text { also thermal conductance } \\ \mathrm{J} & \text { radiosity } \\ \mathrm{k} & \text { thermal conductivity of the air } \\ \mathrm{L} & \text { height of the window air } \\ & \text { cavity } \\ \mathrm{n} & \text { refraction index } \\ \mathrm{N} & \text { number } \\ \mathrm{p} & \text { pressure } \\ \mathrm{q} & \text { heat flux } \\ \mathrm{R} & \text { thermal resistance } \\ \mathrm{s} & \text { thickness of the window air } \\ \mathrm{\gamma} & \text { cavity } \\ \mathrm{T} & \text { temperature } \\ \mathrm{u}, \mathrm{v} & \text { velocity components } \\ \mathrm{U} & \text { thermal transmittance } \\ \mathrm{x}, \mathrm{y} & \mathrm{Cartesian} \text { coordinates } \\ \mathrm{T} & \text { temperature difference } \\ \text { thermal expansion coefficient } \\ \end{array}$

$\begin{array}{rrlr}- & \varepsilon & \text { Emissivity } & - \\ \mathrm{J} / \mathrm{kg} \cdot \mathrm{K} & \lambda & \text { thermal conductivity } & \mathrm{W} / \mathrm{m} \cdot \mathrm{K} \\ - & \mu & \text { dynamic viscosity of air } & \mathrm{kg} / \mathrm{m} \cdot \mathrm{s} \\ \mathrm{m} & \rho & \text { density of air } & \mathrm{kg} / \mathrm{m}^{3} \\ \mathrm{~m} & \sigma & \text { Stefan-Boltzmann constant } & \mathrm{W} / \mathrm{m}^{2} \cdot \mathrm{K}^{4}\end{array}$

Dimensionless Numbers

$\begin{array}{rcl}- & \mathrm{Gr} & \text { Grashof number } \\ \mathrm{m} / \mathrm{s}^{2} & \mathrm{Nu} & \text { Nusselt number } \\ \mathrm{W} / \mathrm{m}^{2} \cdot \mathrm{K} & \mathrm{Pr} & \text { Prandtl number } \\ \mathrm{W} / \mathrm{m}^{2} \cdot \mathrm{K} & \mathrm{Ra} & \text { Rayleigh number } \\ \mathrm{W} / \mathrm{m}^{2} & & \end{array}$

$\mathrm{W} / \mathrm{m} \cdot \mathrm{K} \quad$ Subscripts

m a Air

- C Cold

- e External

g Glass

W $/ \mathrm{m}^{2} \quad \mathrm{H} \quad$ Hot

$\mathrm{m} \cdot \mathrm{K} / \mathrm{W} \quad \mathrm{i} \quad$ internal

M j, k surface name
${ }^{\circ} \mathrm{C} \quad \mathrm{m} \quad$ Mean
n Number

$\mathrm{W} / \mathrm{m}^{2} \cdot \mathrm{K} \quad \mathrm{t} \quad$ Total

- $\mathrm{r}$ Radiation

K $\mathrm{s}$ Slat

$1 / \mathrm{K} \quad \mathrm{W} \quad$ Wall 


\section{1. Introduction}

The 1950s and 60s increasingly saw glass become the material of choice for building façades. In addition to conveying a sense of architectural modernity, the abundant availability of natural light offered scope to significantly reduce demand for artificial lighting energy [1].

Working against this, and an issue of growing concern in response to the more recent sustainability agenda, is the poor thermal insulation properties of glazed façade systems. A Transparent Insulation Material (TIM) structure, sandwiched within a double-glazed unit, is proposed as a strategy to reduce heat transfer through the building envelope while maintaining reasonable levels of daylight.

TIMs can be generally classified into 4 categories as shown in Fig 1: (a) glazingperpendicular structure, (b) glazing-parallel structure, (c) mixed structure and (d) homogeneous structure. There are three typical types of glazing-perpendicular structure: 1) capillary, 2) honeycomb, and 3) parallel slats array [2]. This glazing-perpendicular TIM (Fig 1(a1)-(a3)) divides the air cavity into small horizontal, linear cells. The cell walls provide additional viscous resistance to the onset of free convection and interfere with the thermal radiation transferred from one pane of the double glazed unit to the other, hence increasing the thermal resistance of the glazing system [3]. Glazing-parallel structures (Fig 1(b)) consist of a number of glass or plastic layers lying parallel to the glazing panes. Increasing the number of layers would reduce heat loss but result in reduction in solar and visible transmittance due to the increased reflectance and absorptance provided by the additional layers [2]. Mixed TIM (Fig 1(c)) is a combination of glazing-perpendicular and glazingparallel structure. Homogenous TIM (Fig 1(d)) are receiving increasing attention, with recent research into silica aerogel offering a translucent material that can fill in the air cavity of a double glazed unit (Fig 1(d)). The high porosity of aerogels results in a very low thermal 
1 conductivity (e.g. $0.005-0.02 \mathrm{~W} / \mathrm{mK}$ ) [4]. There are two types of silica based aerogels:

2 monolithic silica aerogel (MSA) and granular silica aerogel (GSA). MSA can be clear enough

3 to see through but the high cost and fragility currently limit commercial uptake [5]. GSA has

4 a low solar transmittance (less than 0.5 ) due to bulk scattering effects and is commonly used

5 in skylights $[6,7]$. The employment of a well-designed TIM structure offers the potential to

6 reduce the heat transfer coefficient of a double-glazed unit and in so doing improve the

7 thermal behaviour of buildings they are employed in.

8

9

10

11

12

13

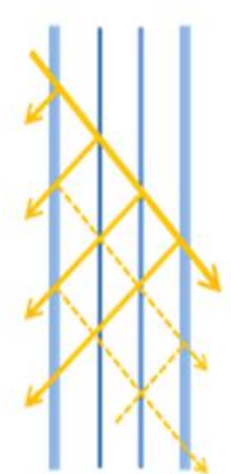

(b)

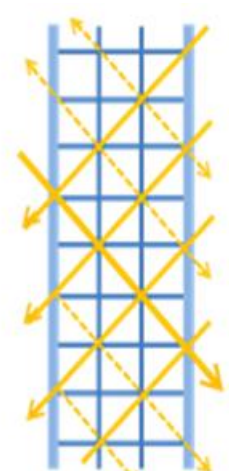

(c)

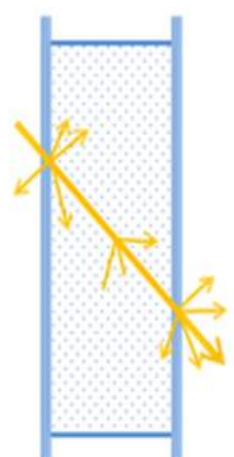

(d)

Fig. 1: Schematic diagram of four typical types of TIM: a) perpendicular structure, b) parallel structure, c) mixed structure and d) homogeneous structure

During the past two decades, the thermal behaviour of glazing-perpendicular TIMs has been investigated numerically and experimentally: much of this work has focused on their application in solar collectors. Arulanantham et al. [8] used a finite difference method to explore the convective stability of horizontal and inclined air cavities enclosed by square honeycomb and concluded that convection suppression was affected by aspect ratio, thickness of wall material and the inclination of cells. Kaushika et al. [9] reported that a honeycomb structure offered better performance for glazing in a horizontal orientation but when inclined to more than $30^{\circ}$ to horizontal, parallel slat structures showed better performance. Kumar and Kaushika [10] found that honeycomb structures of aspect ratio in the range between 10 15 were suitable for convection suppression in air cavities of depth $5 \sim 20 \mathrm{~cm}$ for temperature differences between 20 to $120^{\circ} \mathrm{C}$. Arulanantham and Kaushika [11] numerically studied the combined conductive and radiative heat transfer through a 
1 honeycomb structure in a solar collector and stated that the heat loss coefficient was

2 determined by the interaction between emissivity of honeycomb cell material and plate type

3 of the collector that the honeycomb are employed in. Suehrcke et al. [12] measured the heat

4 transfer coefficient across TIMs made from a high emissivity $(\varepsilon=0.65)$ cellulose acetate

5 (CA) film with both corrugated sheet and honeycomb structure using a guarded hot-plate

6 apparatus and concluded that honeycomb is more effective than corrugated sheet in reducing

7 heat loss.

Studies of the thermal and optical performance of TIMs contained within the cavity of double glazed building windows are relatively few. He et al. [13] measured the performance of honeycomb and parallel slat structure in the cavities of double-glazing units. They found that a honeycomb structure offered the highest thermal resistance, but parallel slat structure offered improved light transmittance (55\% higher than honeycomb at a solar incidence angle of $60^{\circ}$ ). Although the thermal performance of the parallel slat structure was not as good as the honeycomb structure, it did, never the less, offer reductions in heat transfer coefficient in the order of $41 \%$ as compared with a conventional double glazed window. Lien et al. [14] researched performance of a glazing with integrated cappillary TIM in terms of daylight distribution and visual connectivitis (i.e. potential to disrupt view) as well as energy consumption of its application on a row house. Simulation results showed that replacing part of a traditional wall with a TIM wall resulted in annual energy savings of between $16 \%$ and $20 \%$. They also suggested that visual connectivity is related to thickness of the structure as well as the distance and angle between the observer and glazing system. Increasing distance from the window results in an increased range of vision, and increasing the thickness of material results in a decreasing range of vision. Larger diameter capillaries also results in a larger transparent area. Wong et al. [15] conducted a computer simulation of TI-glazing of a 22mm PMMA capillary slab on a south facing façade. The results for a full calendar year 
1 showed that in comparison with standard double glazing, daytime internal temperature

2 swings were reduced and when combined with thermal mass, solar protection and natural

3 ventilation strategies, TIM-glazing has the potential to reduce heating energy load in winter

4 and overheating in summer.

The fundamental thermal and optical characteristics of TIMs integrated within building windows or glazed façades are entirely different from their application in solar thermal collectors but have seen much less research. The conditions experienced by a window that incorporates TIMs are distinct from those in solar collector applications. Firstly, the mean working temperature and temperature difference between two surfaces of a window are much smaller than in a solar collector. Secondly, the natural convection pattern and intensity in the vertical cavity between two glazing panes differ from the convection that occurs within the horizontal space between a hot solar absorber and its cold glass cover. The difference can be explained by the fact that the buoyancy driven natural convection is more significant in the vertical cavity of a window as compared with that in horizontally oriented cavities in collectors. Furthermore the application of TIMs to window design has to account for the additional functions these components commonly provide, namely the provision of view and effective daylight distribution.

Although the thermal and optical performance of TIMs applied to windows have seen relatively little research, the concept of using interstitial structures, such as horizontal Venetian blinds, pleated blinds and different configurations of fins, within the air cavity of a double glazing unit has been widely researched [2,16-31]. These structures share many of the same characteristics as TIMs and offer the potential to improve the U-value of any doubleglazed unit within which they are employed [3, 16, 17]. Wright et al. [18], Naylor et al. [19] and Almeida et al. [20] found that the average convective heat transfer for a double glazing unit reduced when an interstitial blind is present. The scale of this reduction is affected by the 
1 distance between the blind tips and the glazing panes [19]. Studies have also been carried out

2 using Computational Fluid Dynamics (CFD) to analyse the heat transfer and explore the air

3 flow pattern in the cavity of a window with interstitial blinds [3, 17, 21-24]. Results showed

4 that the insertion of horizontal fins in a double glazing unit causes a reduction of global heat

5 transfer of about $30 \%$ under the thermal conditions commonly encountered in building

6 applications [24]. Gome et al. [25] developed a net radiation method for determining both

7 solar and visible optical properties of glazing with shading devices, particularly venetian

8 blinds. In order to analyse optical performance, a ray-tracing technique was validated [26-28]

9 and used to provide the lighting transmittance [29]. In terms of objectively assessing the

10 visual connectivity through a window with blinds or other shading system, Tzempelikos [30] used projected view (or shaded) fractions as a function of rotation angle, taking into account edge effects and slat thickness, while Konstantzos et al. [31] undertook a field study to promote a metric describing view clarity.

The literature suggests that the integration of glazing-perpendicular TIM structures in the air cavity of a double glazing unit will increase the thermal resistance of the glazing system without significant sacrifice of solar transmittance. The work presented in this paper details the optical and thermal analysis of Parallel Slat TIM (PS-TIM) structures that were sandwiched in between two glazing panes of a double glazing unit. A two-dimensional model was developed using the commercial CFD package FLUENT to explore the convective, conductive and radiative heat transfer that occurs in the double glazing air cavity with and without PS-TIM. A variety of cell aspect ratios, slat thicknesses and slat thermal properties (conductivity and emissivity) were examined to investigate their effects on overall thermal performance. These studies were used to calculate the U-value for the different configurations of PS-TIM and glazing. Finally a ray-tracing tool, TracePro, was used to analyse the optical transmittance of the systems under different solar incidence angles. 


\section{2. Thermal Modelling}
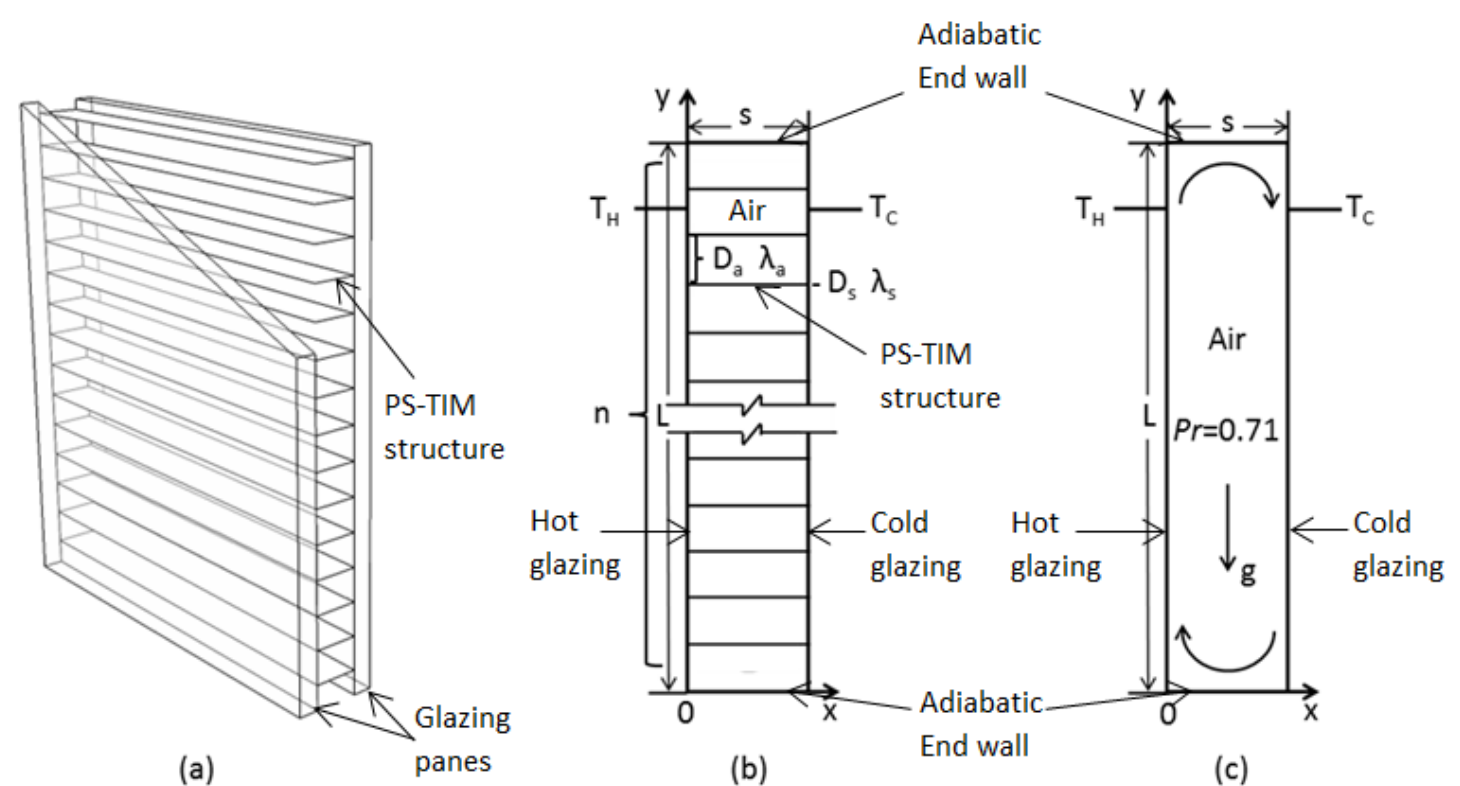

Fig. 2. (a) PS-TIM structure in a double-glazing unit; (b) 2D schematic illustrating the geometry of the air gap with PS-TIM structure; (c) 2D schematic illustrating geometry of air gap without PS-TIM.

Schematic diagrams illustrating the geometry of a double glazing unit with and without a PS-TIM structure are shown in Fig. 2. The double-glazing unit was assumed to have an air cavity of thickness $15 \mathrm{~mm}$ between panes that were $300 \mathrm{~mm}$ in height. This was investigated with 4 different PS-TIM geometries where the interval distance between neighbouring slats, $\mathrm{D}_{\mathrm{a}}$, was assumed to be $3 \mathrm{~mm}, 5 \mathrm{~mm}, 7.5 \mathrm{~mm}$ and $10 \mathrm{~mm}$.

\subsection{Governing equations and assumptions}

Two-dimensional finite volume models were developed in the commercial CFD package FLUENT. To simplify the CFD simulation process, the following assumptions were made: 1) the glass surfaces facing into the cavity were set as two isothermal walls with different temperatures to represent the temperature difference between indoor and outdoor environments; 2) the top and bottom surfaces bounding the cavity were assumed to be adiabatic; 3) the enclosure was filled with air whose thermophysical properties (density, viscosity, thermal conductivity) are detailed in Table 1;4) the working fluid, air, has a Prandtl number of approximately 0.71 . 

cavity and cells remains laminar, because the Grasholf Numbers do not reach the related

3 critical value [22]. The governing equations are:

4 Mass balance:

5

$$
\frac{\partial u}{\partial x}+\frac{\partial v}{\partial y}=0
$$

Momentum balance:

7

$$
\begin{gathered}
\rho\left(u \frac{\partial u}{\partial x}+v \frac{\partial u}{\partial y}\right)=-\frac{\partial p}{\partial x}+\mu\left(\frac{\partial^{2} u}{\partial x^{2}}+\frac{\partial^{2} u}{\partial y^{2}}\right) \\
\rho\left(u \frac{\partial v}{\partial x}+v \frac{\partial v}{\partial y}\right)=-\frac{\partial p}{\partial x}+\mu\left(\frac{\partial^{2} v}{\partial x^{2}}+\frac{\partial^{2} v}{\partial y^{2}}\right)+\rho g \beta\left(T-T_{C}\right)
\end{gathered}
$$

Energy balance:

$$
\rho c_{p}\left(u \frac{\partial T}{\partial x}+v \frac{\partial T}{\partial y}\right)=k\left(\frac{\partial^{2} T}{\partial x^{2}}+\frac{\partial^{2} T}{\partial y^{2}}\right)\left(+S_{h}\right)
$$

In order to evaluate the effect of the parallel slat structure on convection, the radiative heat transfer between the two glazing panes was initially neglected (this is referred to as the convection-only model). Radiation, conduction and convection were included in the full model, which was used to calculate the overall scale of heat transfer through the air cavity and the resulting $\mathrm{U}$-value of the glazing system.

In the full model, radiative heat transfer, $S_{h}$ in equation (4), was solved using the Surface to Surface (S2S) radiation method. All the surfaces were assumed to be grey bodies, diffuse and opaque to thermal radiation. The air in the cavity was assumed to be a nonparticipating medium. The view factors $\left(\mathrm{F}_{\mathrm{kj}}\right)$, which depend on surfaces' size, separation distance and orientation were computed before the simulating radiation.

The S2S method can be represented by the following equation: 


$$
\mathrm{J}_{\mathrm{k}}=\varepsilon_{\mathrm{k}} \sigma \mathrm{T}_{\mathrm{k}}^{4}+\left(1-\varepsilon_{\mathrm{k}}\right) \sum_{\mathrm{j}=1}^{\mathrm{N}} \mathrm{F}_{\mathrm{kj}} \mathrm{J}_{\mathrm{j}}
$$

In both models, all thermophysical properties of the fluid were assumed to be constant (e.g. $\left.C_{p}, k\right)[21,23,24]$ except for the fluid density and viscosity. Variation of density $\rho$ in response to temperature change was treated by means of the Boussinesq approximation. The equation is given as follows:

$$
\rho=\rho_{0}\left[1-\beta\left(T-T_{0}\right)\right]
$$

where $\rho_{0}$ is the (constant) density of the air at the mean surface temperature $\left(T_{0}\right)$, and $\beta$ is the thermal expansion coefficient.

The viscosity was assumed to vary in response to temperature according to piecewiselinear equation as follows:

$$
\mu(T)=\mu_{n}+\frac{\mu_{n+1}-\mu_{n}}{T_{n+1}-T_{n}}
$$

where $1 \leq \mathrm{n} \leq \mathrm{N}$ and $\mathrm{N}$ is the size of the temperature intervals.

\subsection{Boundary conditions and material properties}

The material properties (conductivity, thickness and emissivity) of the PS-TIM structure were varied to explore their influences on the overall performance of the window using the full model. Detailed properties can be found in Table 1. From this it may be seen that, four temperature differences between the two glazing panes $(10 \mathrm{~K}, 20 \mathrm{~K}, 30 \mathrm{~K}$ and $40 \mathrm{~K})$ were set as the boundary conditions and their mean temperature was maintained at $10^{\circ} \mathrm{C}$ $(283 \mathrm{~K})$.

\section{Table 1}

Properties and boundary conditions for different models.

$\begin{array}{lll}\text { Air Properties: } & & \\ \text { Specific heat }(\mathrm{J} / \mathrm{kg} \cdot \mathrm{K}) & \text { Conductivity }(\mathrm{W} / \mathrm{mK}) & \text { Thermal expansion coefficient }(1 / \mathrm{K}) \\ 1005 & 0.025 & 0.00353\end{array}$

Convection- PS-TIM properties: 


$\begin{array}{llll}\text { only model } & \text { Conductivity }(\mathrm{W} / \mathrm{mK}) & \text { Thickness }(\mathrm{mm}) & \text { Emissivity } \\ 0.15 & 0.1 & 0.65\end{array}$

Boundary conditions (refer to Fig. 2):

$\begin{array}{llll}\text { Left wall }(\mathrm{K}) & \text { Right wall }(\mathrm{K}) & \text { Top end } & \text { Bottom end }\end{array}$

288/293/298/303 278/273/268/263 Adiabatic Adiabatic

Air Properties: Same as 'convection-only model'

Convection- PS-TIM properties

conduction- Conductivity $(\mathrm{W} / \mathrm{mK}) \quad$ Thickness $(\mathrm{mm}) \quad$ Emissivity

radiation $\quad 0.1 / 0.2 / 0.3 / 0.4 / 0.5 \quad 0.05 / 0.1 / 0.15 / 0.2 \quad 0.3 / 0.65 / 0.84$

model Boundary conditions: Same as 'convection-only model'

Air Properties: Same as 'convection-only model'

PS-TIM properties: Same as 'convection-only model'

Convection- Boundary conditions (refer to Fig. 2):

$\begin{array}{lllll}\text { conduction- } & \text { Left wall }(\mathrm{K}) & \text { Right wall }(\mathrm{K}) & \text { Top end } & \text { Bottom end } \\ \text { radiation } & 290.5 & 275.5 & \text { Adiabatic } & \text { Adiabatic } \\ \text { model for } & \text { Glass Properties: } & & \\ \text { U-value } & \text { Conductivity }(\mathrm{W} / \mathrm{mK}) & \text { Thickness }(\mathrm{mm}) & \text { Emissivity } & \\ \text { calculation } & 0.94 & 4 & 0.84\end{array}$

Surface heat transfer coefficient:

$\begin{array}{llll}\text { External }\left(\mathrm{W} / \mathrm{m}^{2} \mathrm{~K}\right) & 25 & \text { Internal }\left(\mathrm{W} / \mathrm{m}^{2} \mathrm{~K}\right) & 7.7\end{array}$

\section{$1 \quad 2.3$ Model validation}

2 Extensive mesh independence and iterative convergence studies were undertaken. In

3 the final model, smaller size meshes with dimension $0.025 \mathrm{~mm} \times 0.025 \mathrm{~mm}$ were arranged

4 near the two glazing surfaces, which then gradually increased in size toward the centre of the

5 cavity. In addition, to confirm the validity of the numerical model, the predicted average heat

6 fluxes across a double glazed window $(1200 \mathrm{~mm} \times 1200 \mathrm{~mm} \times 28 \mathrm{~mm})$ with and without

7 horizontal Venetian blinds positioned in the air cavity were compared with experimental data

8 obtained from a series of tests in a large climatic chamber (TAS Series 3 LTCL600) at the 
1 Energy Technologies Building, Faculty of Engineering, University of Nottingham, UK. The

2 detailed experimental setup and measurements are explained in Sun et al. [3]. The average

3 heat flux across the two glazing panes measured under a controlled surface temperature

4 difference across the window is shown in Fig. 3. Attempts were made to maintain the average

5 surface temperature of the window for all these tests at approximately $10^{\circ} \mathrm{C}(283 \mathrm{~K})$. The

6 surface temperature difference between the hot and cold side were varied from $7.5 \mathrm{~K}$ to 15.5

7 K. From Fig. 3, it can be seen that CFD simulation and experimental measurements show

8 reasonable agreement with differences of less than $1 \%$.

9

10 Fig. 3: Comparison of CFD simulation results with experimental results

\section{$\diamond$ Exp.-Double glazing}

*CFD-Double glazing

$\triangle$ Exp.-DG with blinds

$\times$ CFD-DG with blinds

\subsection{Derivation of thermal transmittance}

The local convective heat flux and combined convective and radiative heat flux can

13 be obtained from the converged temperature field in the CFD simulation. The results of 14 convective heat flux at the boundaries of two glazing panes were used to express the local 15 Nusselt number $(\mathrm{Nu})$ using equation (8):

$$
\mathrm{Nu}=\frac{\left(\frac{\partial \mathrm{T}}{\partial \mathrm{x}}\right)_{\mathrm{w}} \mathrm{s}}{\Delta \mathrm{T}}=\frac{\mathrm{qs}}{\lambda_{\mathrm{a}} \Delta \mathrm{T}}
$$


1 where $\left(\frac{\partial \mathrm{T}}{\partial \mathrm{x}}\right)_{\mathrm{W}}$ is the air temperature gradient on the glazing surface and $\mathrm{q}\left(\mathrm{W} / \mathrm{m}^{2}\right)$ is the average

2 convective heat flux across the two surfaces. $\Delta \mathrm{T}(\mathrm{K})$ is the temperature difference between the

3 hot and cold isothermal surfaces.

4

5 resistances to a convection resistance [32], is an important dimensionless coefficient that

6 indicates the intensity of convection. It is affected by three dimensionless parameters: the

7 aspect ratio of the cavity; the Prandtl number and the Grasholf number of the fluid. The

8 aspect ratio $\left(A=\frac{L}{s}\right.$, for the plane double glazed unit, or $A=\frac{D_{a}}{s}$, for the PS-TIM unit)

9 describes the geometry of the air cavity. The Prandtl number $\left(\operatorname{Pr}=\frac{c_{p} \mu}{\lambda_{a}}\right)$ describes the ratio of

10 momentum diffusivity to thermal diffusivity and the Grasholf number $\left(\mathrm{Gr}=\frac{\mathrm{g} \beta \Delta \mathrm{Ts}^{3} \rho^{2}}{\mu^{2}}\right)$

11 describes the relationship between buoyancy and viscosity within a fluid.

13 can be expressed in equation (9):

$$
\mathrm{h}_{\text {no-slat }}=\frac{\left(\frac{\partial \mathrm{T}}{\partial \mathrm{x}}\right)_{\mathrm{w}} \lambda_{\mathrm{a}}}{\Delta \mathrm{T}}=\frac{\mathrm{q}^{\prime}}{\Delta \mathrm{T}}
$$

15 where $\mathrm{q}^{\prime}$ is the average heat flux of combined convective and radiative heat transfer across 16 the two surfaces.

Inclusion of the PS-TIM gives the thermal conductance as:

$$
\mathrm{h}_{\mathrm{PS}-\mathrm{TIM}}=\frac{\mathrm{q}^{\prime}}{\Delta \mathrm{T}} \cdot \frac{\mathrm{D}_{\mathrm{a}} \mathrm{n}}{\mathrm{L}}+\frac{\lambda_{\mathrm{s}}}{\mathrm{s}} \cdot \frac{\mathrm{D}_{\mathrm{s}}(\mathrm{n}-1)}{\mathrm{L}}
$$

where $D_{a}$ is the distance between two neighbouring slats, $D_{s}$ is the thickness of the slat, $n$ is the number of slats and $\mathrm{L}$ is the height of the window. 
$2 \mathrm{~h}_{\text {no-slat }}$ ) here describes the heat transfer coefficient through the air cavity, which includes the 3 convective and conductive heat transfer through the air, conductive heat transfer through the

4 PS-TIM structure and the radiative heat transfer from internal to external surfaces. Once this 5 was obtained through CFD simulation, the U-value of the whole unit can be calculated 6 separately using the following procedure. Firstly, the thermal resistance of the glazing unit (R) 7 is obtained from:

$$
\mathrm{R}=\frac{1}{\mathrm{~h}}+\frac{2 \mathrm{~d}}{\lambda_{\mathrm{g}}}
$$

where $\mathrm{d}$ is the thickness of each glass pane, and $\lambda_{\mathrm{g}}$ is the thermal conductivity of the glass (W/mK). The two glazing panes were assumed to be ordinary soda-lime silica float glass with thickness of $4 \mathrm{~mm}$, thermal conductivity of $0.94 \mathrm{~W} / \mathrm{mK}$ and emissivity of 0.84 (see Table 1). The thermal conductance, U-value, of the unit can be expressed as:

$$
\frac{1}{\mathrm{U}}=\frac{1}{\mathrm{~h}_{\mathrm{e}}}+\mathrm{R}+\frac{1}{\mathrm{~h}_{\mathrm{i}}}
$$

where, $h_{e}$ and $h_{i}$ are the external and internal surface heat transfer coefficients, respectively. For normal exposure of panes, $h_{e}=25 \mathrm{~W} / \mathrm{m}^{2} \mathrm{~K}$ and $h_{i}=7.7 \mathrm{~W} / \mathrm{m}^{2} \mathrm{~K}$ are assumed [33]. For the purpose of normalization of the calculated U-value, the temperature difference between

17 the bounding glass surfaces was kept at $15 \mathrm{~K}$, while the mean temperature was kept at $10^{\circ} \mathrm{C}$ (see Table 1$)[33,34]$.

\section{3. Ray tracing technique}

To assess the optical performance for this glazing system, a commercial ray tracing program TracePro, which is based on forward ray tracing technique, was used to simulate the solar transmittance of the glazing system at different solar incidence angles. Forward ray tracing follows the photon in the direction that light travels, ie, from the source to the receiving 
1 surfaces. In the simulation, radiation with known intensity is applied incident to the aperture

2 of the glazing system with each ray carrying the same amount of energy. The transmitted,

3 reflected and absorbed radiation intensities in the glazing system can be calculated by the tray

4 tracing program. After an initial process of ray dependence testing, 10,000 rays were applied

5 on the aperture containing the glazing. Fig.4. illustrates a cross sectional view of the ray

6 tracing simulation used for the glazing system at two different solar incidence angles. Only

720 rays are shown in (b) and (c) for the purpose of clarity, allowing the path of individual

8 rays to be visualised. The glass panes are $4 \mathrm{~mm}$ thick, with refraction index of 1.52 and

9 absorption of 0.01 per $\mathrm{mm}$. The transparent slats are thin enough for absorption within the

10 material to be neglected, and this material has a transmittance of 0.99 and reflectance of 0.01 .

11 To avoid the edge effect, ray tray simulation was applied to a central $400 \mathrm{~mm}$ by $400 \mathrm{~mm}$ area of a larger glazing system with dimensions of $700 \mathrm{~mm}$ by $1400 \mathrm{~mm}$.

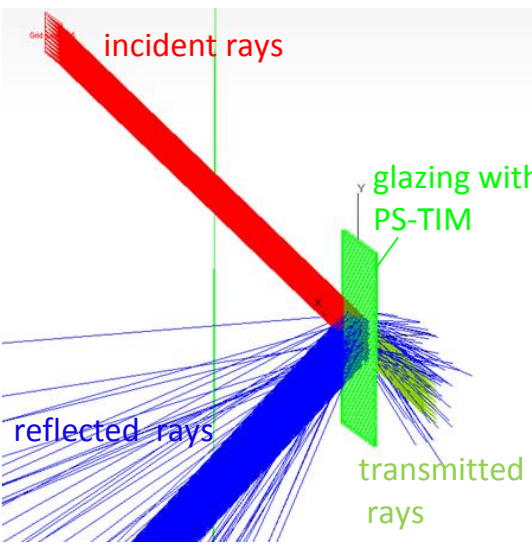

(a)

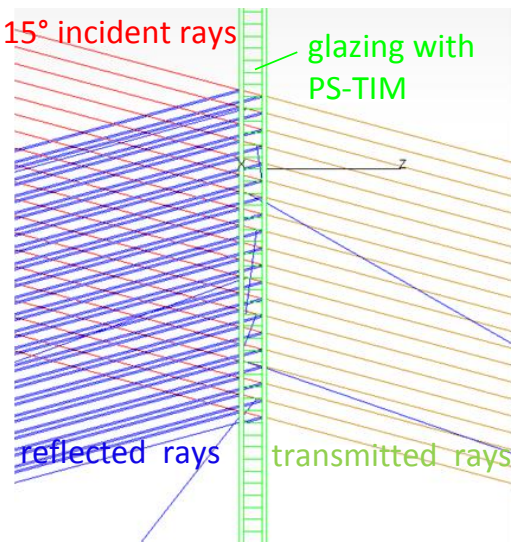

(b)

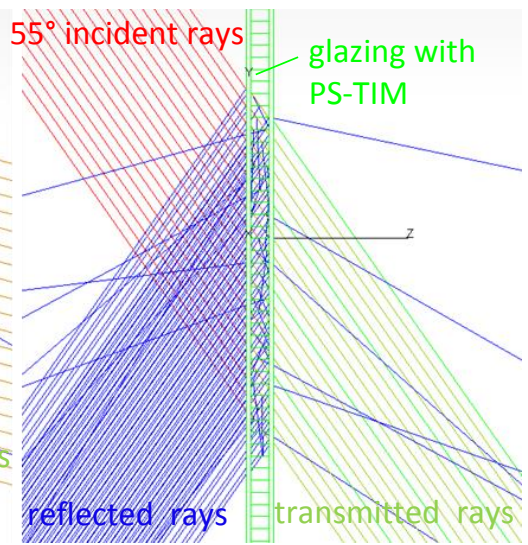

(c)

Fig. 4: (a) simulation model in TracePro (b) ray tracing plot for $15^{\circ}$ incidence angle (c) ray tracing plot for $55^{\circ}$ incidence angle

\section{Results and discussion}

In this section, the simulation results for convective, conductive and radiative heat transfer through the PS-TIM structure located in the cavity of double-glazing units are discussed. The overall U-value and optical performance of the PS-TIM system are presented. 


\section{4.1 Effect of aspect ratio on convective suppression}

The PS-TIM structure is proposed as a means of suppressing convective heat transfer in the air cavity of a double-glazing unit. However, it is useful to understand the free convection that occurs in a single air cavity formed between neighbouring slats and how changing the distance between them, $\mathrm{D}_{\mathrm{a}}$, influences convective suppression. In this section, the influence of aspect ratio of a double-glazing unit (illustrated in Fig. 2(c)) and the aspect ratio of a PS-TIM cell (shown in in Fig. 2 (b)) in providing convective suppression are investigated. In order to realize the variation of aspect ratio, the width of the air cavity between the two glazing panes was fixed and the spacing between slats was changed. Under these circumstances, variation of the Grashof number depends only on the temperature difference between the two vertical glazing surfaces (when $\Delta \mathrm{T}=10 \mathrm{~K}, 20 \mathrm{~K}, 30 \mathrm{~K}$ and $40 \mathrm{~K}, \mathrm{Gr}$ $=5000,10000,15000$ and 20000 respectively).

Fig. 5 shows the relationship between the Nusselt number and aspect ratio at different Grashof numbers for a single air cavity. Fig. 5 (b) presents data for air cavities with aspect ratios representative of those observed in conventional double-glazing units. Fig. 5 (a) presents data for aspect ratios that are representative of the cells present in a PS-TIM structure. It can be seen that the Nusselt number reaches the peak value when the aspect ratio is equal to 1 . This means that a square cavity provides the smallest viscous resistance to the onset of free convection. In the range of $\mathrm{A}=1$ to 100 , the Nusselt number decreases in response to increasing of aspect ratio. This occurs rapidly up to a value of $A=30$. Thereafter the Nusselt number decreases only gradually. This indicates that the shape of the vertical space has significant influence on the free convection until it becomes sufficiently tall. In the range of $\mathrm{A}=1$ to 100 , a high Grashof number leads to a high Nusselt number. This means that a higher temperature difference increases the convection in the cavity; therefore the convective heat transfer cannot be fully suppressed over the temperature range examined. 
1 When the aspect ratio is less than 1, for practical purposes, this would represent a single cell

2 in a double glazed unit where the slat spacing is less than the cavity width. Fig.5 (a) shows

3 that the Nusselt number declines sharply until it reaches $\mathrm{Nu}=1$ at $\mathrm{A}=0.35$ over the range of

4 the Grashof number spanning 5000 to 20,000. This indicates that at the scale of a window,

5 the introduction of the slats and their influence on the geometry of the cell is capable of

6 achieving full convection suppression. This occurs because the resulting resistance is

7 sufficiently high that no matter what the temperature difference between the two panes is

8 convection is not initiated.

9

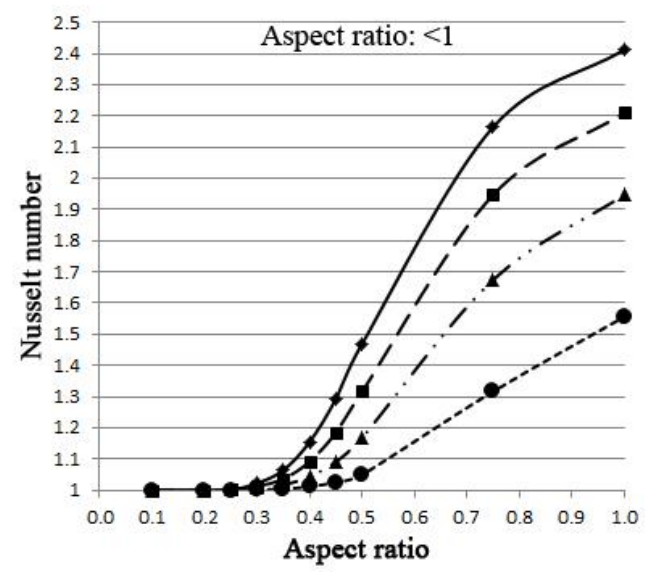

(a)

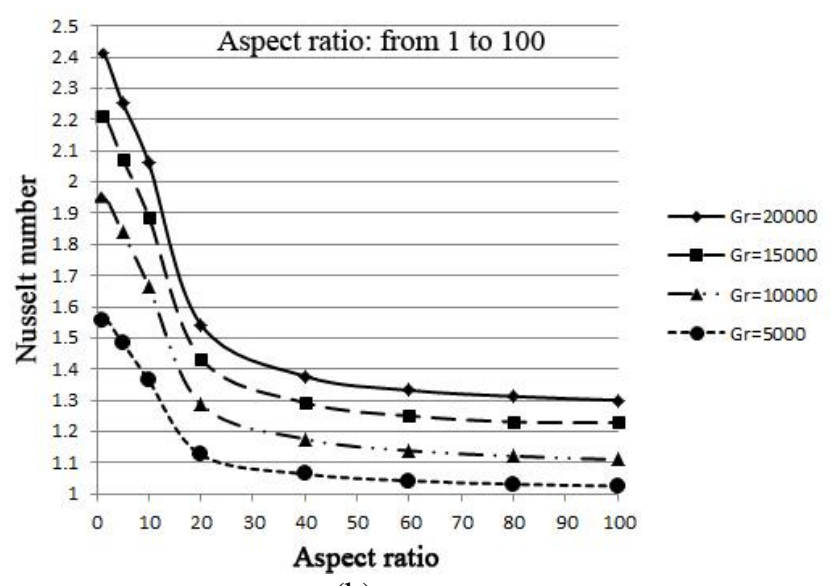

(b)

Fig. 5: Relationship of the Nusselt number vs Aspect ratio for different Grashof number for (a) small cells and

(b) double glazing units.

\subsection{Thermal visualisation within the PS-TIM structures}

From section 4.1, it can be seen that creating small horizontal rectangular cells leads

to full convection suppression within an air cavity of a double glazing unit. Achieving this through the introduction of a PS-TIM structure with small cells was therefore studied further to visualise the effects of slat interval distance on the convective heat transfer. Four interval distances $\left(D_{a}=3 \mathrm{~mm}, 5 \mathrm{~mm}, 7.5 \mathrm{~mm}\right.$ and $\left.10 \mathrm{~mm}\right)$ were analysed and also compared with a cavity containing no slats. 
2 when $\mathrm{Gr}=5000$, the fluid travels upwards near the hot surface, and downwards adjacent to

3 the cold surface, describing a primary convection cell. When the Gr number is larger than

41000 , secondary cells start to present, which interfere with the isothermal profile. For the 10

$5 \mathrm{~mm}$-cell structure, the curving profile of the isotherms indicates that thermally-induced

6 buoyant flow is present, forming a convective cell. However, for the PS-TIM with 3mm- and

$75 \mathrm{~mm}$-cell structures (and the $7.5 \mathrm{~mm}$-cell structure when $\mathrm{Gr}=5000$ ), the isotherms are

8 uniformly spaced, indicating the heat transfer is conductive in nature. The relationship

9 between the average Nusselt number and Grasholf numbers shown in Fig. 7, illustrates the

10 effect of convection suppression. The PS-TIM with a $10 \mathrm{~mm}$-cell structure provides less

11 convection suppression as the average Nusselt number is similar to, or larger than, that for the

12 cavity without slats at same Grasholf number. This is because the viscous resistance of a

$1310 \mathrm{~mm}$-cell is generally less than the tall vertical air cavity of the double glazing unit. For the

14 PS-TIM with a 7.5mm-cell structure, although its Nusselt number increases with Grashof

15 number, it only reaches 1.2 , which indicates that over the range of Grashof numbers studies

16 the convective heat transfer is not significant [35]. Free convection within $3 \mathrm{~mm}$ and 5mm-

17 cell structures is almost fully suppressed over the range of the Grashof number from 5000 to

18 20,000. The visualisations therefore suggest that PS-TIMs with 3mm, 5mm and 7.5mm-cell

19 structures can significantly reduce the average Nusselt number and hence reduce convective

20 heat transfer rate, when compared with the air cavity without PS-TIM slats at the same

21 Grashof number. 

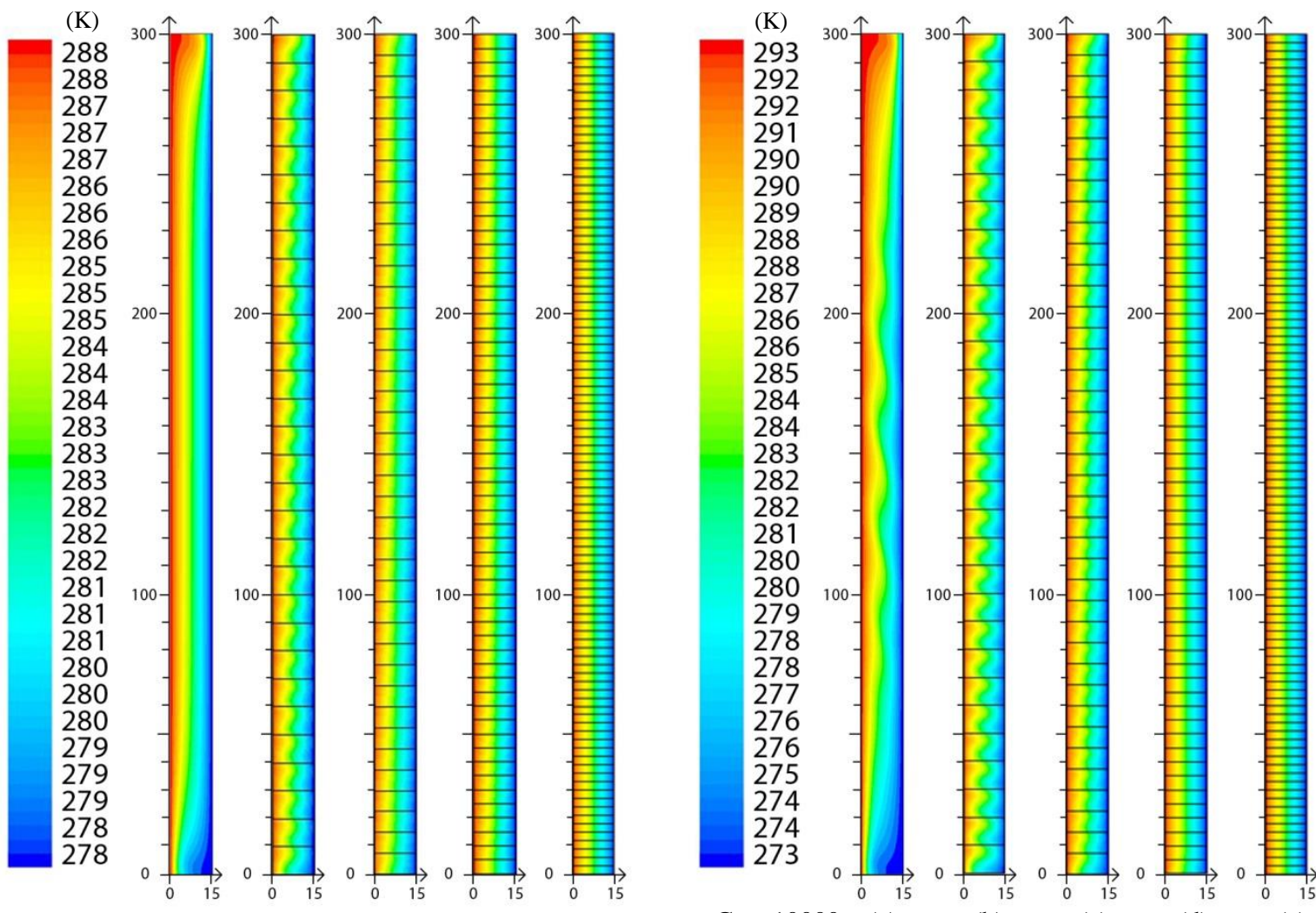

1

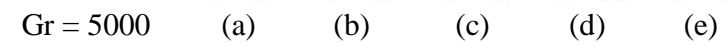

$\mathrm{Gr}=10000 \quad$ (a)

(b)

(c)

(d)

(e)
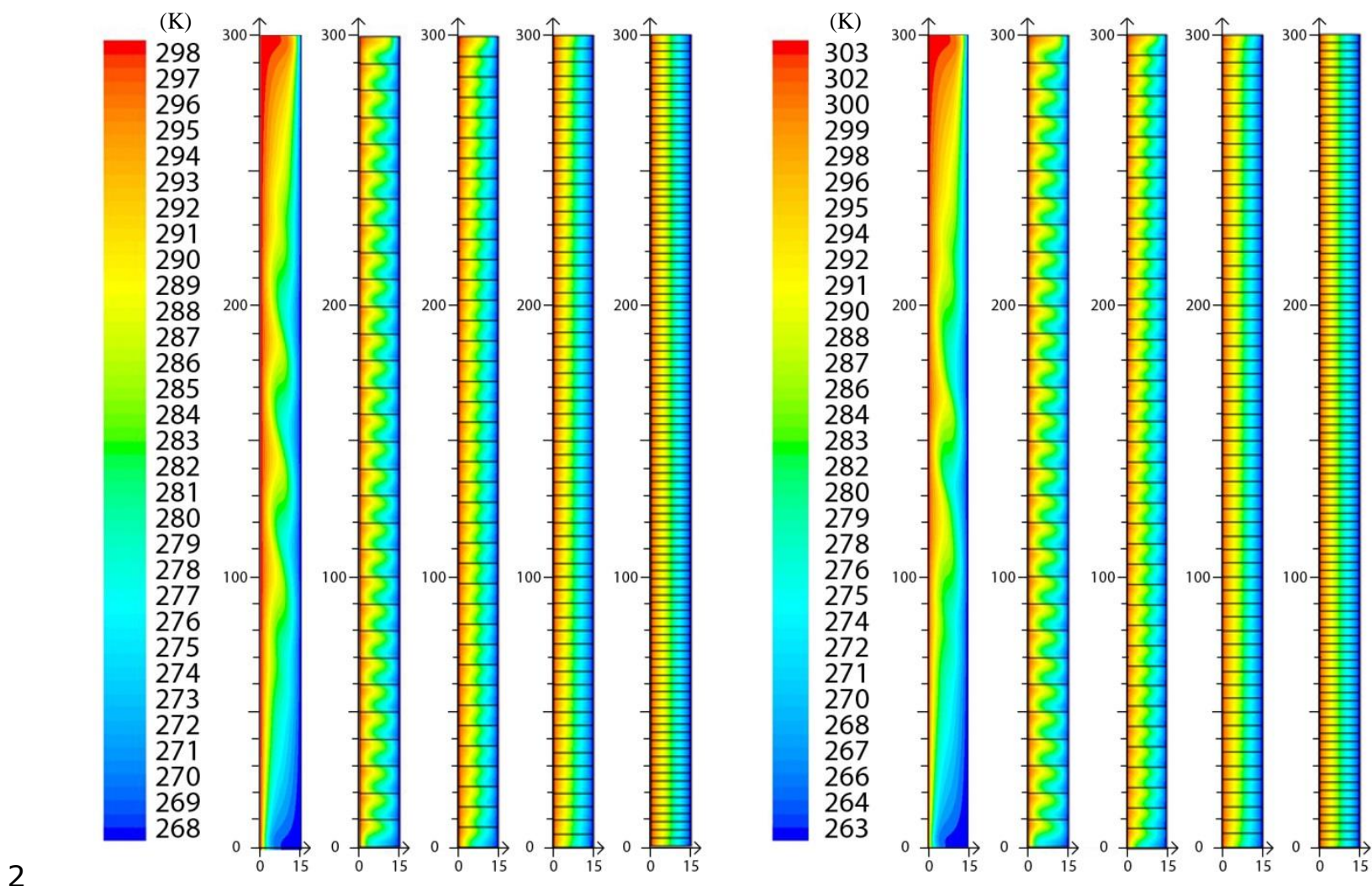

$\mathrm{Gr}=15000$

(a)

(b)

(c)

(d)

(e)

$\mathrm{Gr}=20000 \quad$ (a)

(b)

(c)

(d)

(e)

3 Fig. 6: Temperature profile of a double glazing unit with and without PS-TIM structures at different Grasholf

4 number: (a) no-slats; (b) 10mm-cell structure; (c) 7.5mm-cell structure; (d) $5 \mathrm{~mm}$-cell structure; (e) $3 \mathrm{~mm}$-cell

structure 


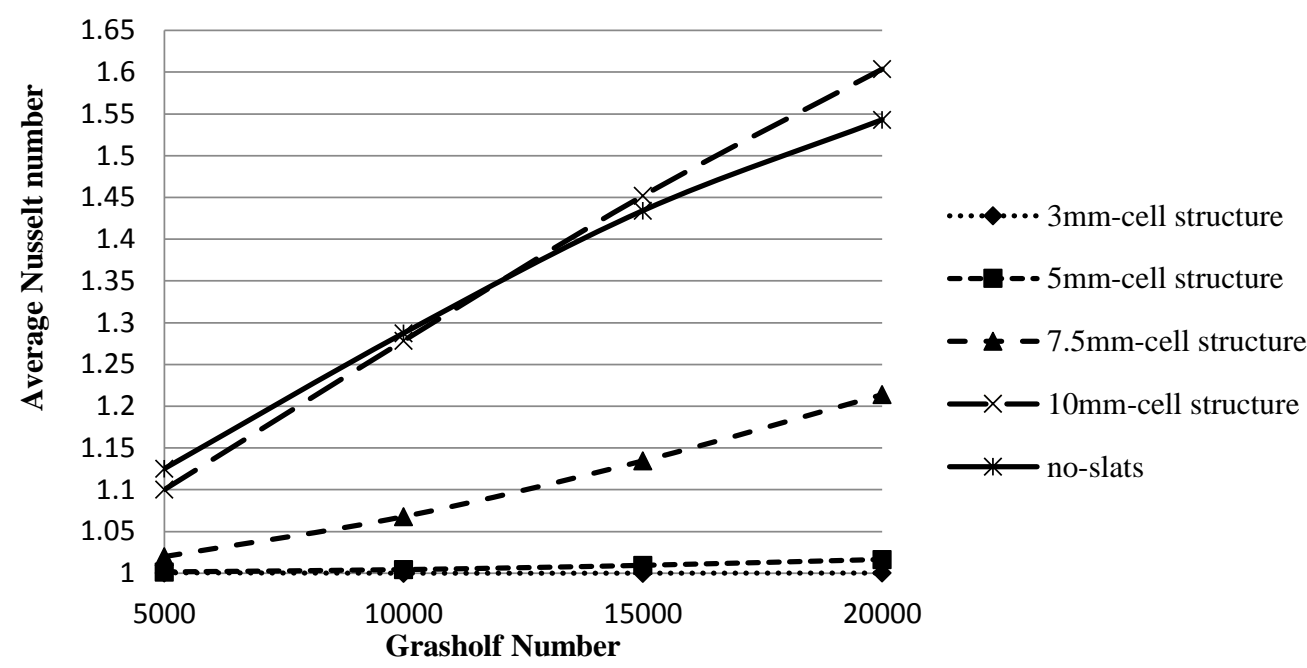

Fig. 7. Relationship between the average Nusselt number and Grasholf numbers for different cell heights

\subsection{Thermal conductance of an air cavity with PS-TIM structures}

In this section, the full model was used to investigate the thermal conductance of the air cavity with and without PS-TIM structures. The thermal conductance predicted using equations (9)-(10) at various temperature differences between the hot and cold glazing surfaces is shown in Fig. 8. The thermal conductance of the system is the sum of conductive heat transfer through the slat (when PS-TIM structures are present), conductive and convective heat transfer through the air and radiative heat transfer. Radiative heat transfer remains constant in each structure due to the constant mean temperature of $10 \mathrm{~K}$ between the two surfaces and for these simulations represents the dominant heat transfer mechanism, accounting for $50 \%-68 \%$ of heat transfer in all the structures examined. Thus, a significant reduction of radiative heat transfer caused by the presence of a PS-TIM structure yields a significant reduction of the total thermal conductance. The scale of this reduction is related to the PS-TIM cell size - for example, 10mm-cells reduced the radiative heat transfer by over $25 \%$. when compared with that of the no-slat structure and $3 \mathrm{~mm}$-cells yielded reductions in the order of $50 \%$, Conductive heat transfer through the material used to form the slats in the PS-TIM is not significant in these simulations. With a sectional thickness $D_{s}=0.1 \mathrm{~mm}$ and a conductivity $\lambda_{s}=0.15 \mathrm{~W} / \mathrm{mK}$, conduction accounts for less than $8 \%$ of total heat flow in the 
1 PS-TIMs with $3 \mathrm{~mm}$ and $5 \mathrm{~mm}$-cells and less than $2.7 \%$ in the PS-TIMs with $7.5 \mathrm{~mm}$ and 2 10mm-cells.

Fig. 9 shows the overall effect on heat transfer resulting from the introduction of PS-

4 TIM, into a glazing unit. This is quantified using the thermal conductance ratio $\mathrm{h}_{\text {Ps-TIM }} / \mathrm{h}_{\text {no-slat }}$ 5 (see equation (10) and equation (9)). As can been seen in Fig. 9, all of the four PS-TIM 6 structures studied are able to provide reduction in thermal conductance as compared with a 7 standard double glazing unit over the assumed range of temperature difference. In general, 8 the smaller the PS-TIM cell height, the smaller the thermal conductance is. For PS-TIMs with $93 \mathrm{~mm}, 5 \mathrm{~mm}$ and $7.5 \mathrm{~mm}$-cell, increasing temperature difference sees improved performance, 10 i.e. the thermal conductance ratio decreases. For example, the $3 \mathrm{~mm}$-cell PS-TIM can achieve 11 a $34.5 \%$ decrease of thermal conductance for a $10 \mathrm{~K}$ temperature difference and a $45 \%$ 12 decrease when the temperature difference is $40 \mathrm{~K}$. This is because, in moving from a temperature difference of $10 \mathrm{~K}$ to $40 \mathrm{~K}$, the heat transfer due to air convection decreased 14 from $14 \%$ to $37 \%$, while the reduction in heat transfer due to radiation remains constant at 15 around $50 \%$. On the other hand, the $10 \mathrm{~mm}$-cell PS-TIM shows an opposite trend to that apparent in the other three structures. The primary benefit of the slats in this geometry is in their ability to reduce view angles and hence reduce radiative heat transfer. The geometry they create, however, lead to increase in convective heat transfer as the temperature difference between the glazing panes is increased. The overall reduction of thermal resistance of the $10 \mathrm{~mm}$-cell PS-TIM is $16.4 \%$ (at $10 \mathrm{~K}$ ) to $15 \%$ (at $40 \mathrm{~K}$ ). 


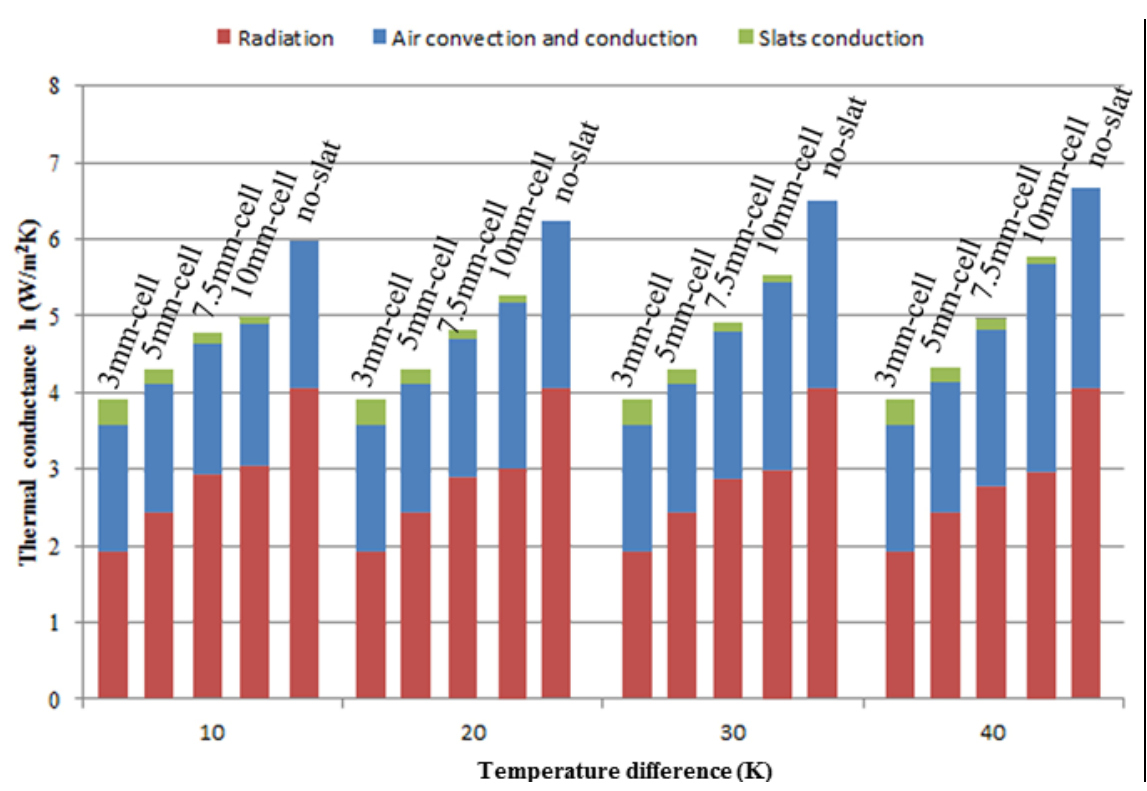

1

2

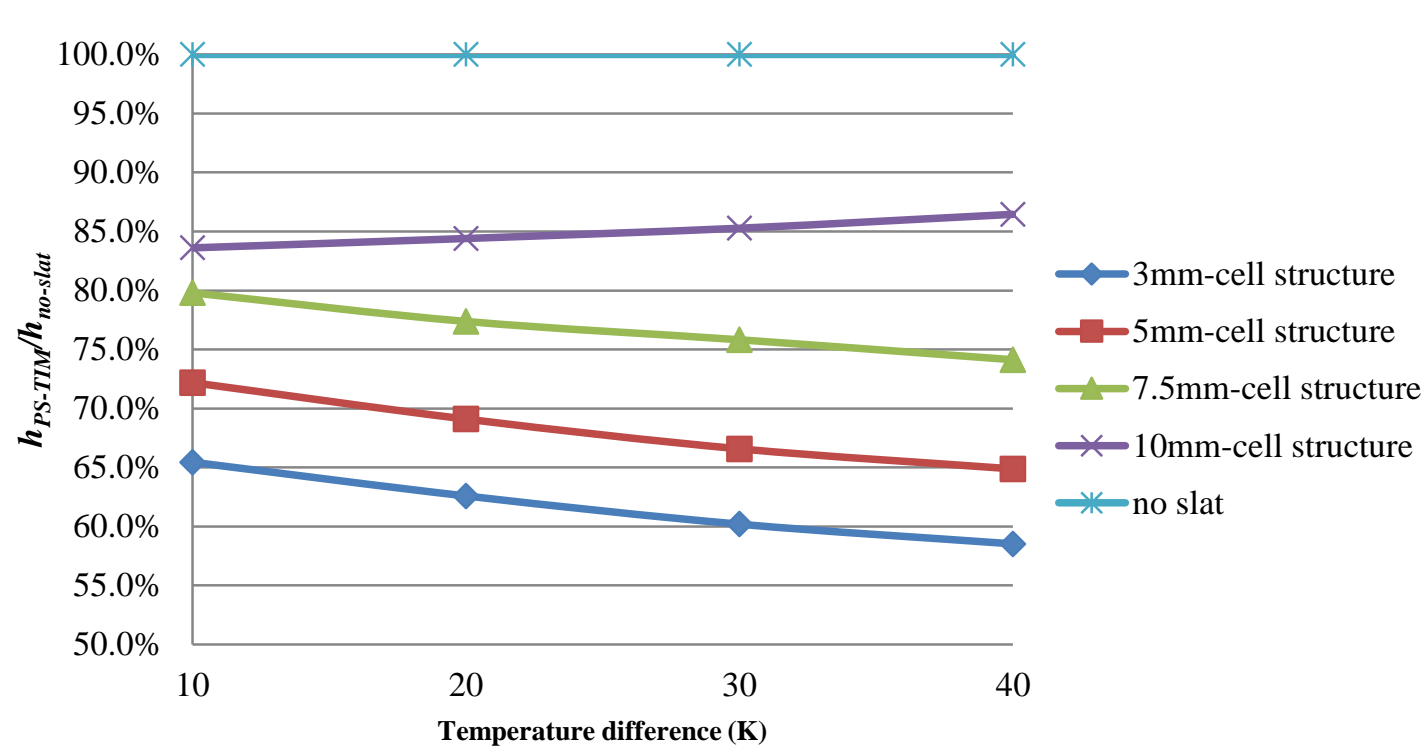

Fig. 8. Thermal conductance caused by conduction, radiation and convection for an air cavity with and without PS-TIMs with different cell dimension at various glazing pane temperature differences

Fig. 9. Ratio of thermal conductance of an air cavity with PS-TIMs with different cell dimension to an air cavity without PS-TIM at various glazing pane temperature differences

\subsection{The effects of slat conductivity, thickness and emissivity on the thermal performance of PS-TIM}

In this section, the effects of slat conductivity, thickness and emissivity on the overall thermal conductance of a double glazed window containing PS-TIM are discussed. Again, the ratio of the thermal conductance of the window with PS-TIM to the thermal conductance 
1 of a standard double glazing unit, the window without TIM, (hPS-TIM $/ \mathrm{h}_{\text {no-slat }}$ ) is used to

2 quantify these effects. Data for the PS-TIM with $3 \mathrm{~mm}, 5 \mathrm{~mm}$ and $7.5 \mathrm{~mm}$-cells, where

3 convection is effectively suppressed, showed similar trends, therefore only the $3 \mathrm{~mm}$ data are

4 presented. These are compared with data for the PS-TIM with 10mm-cells where convection

5 is present.
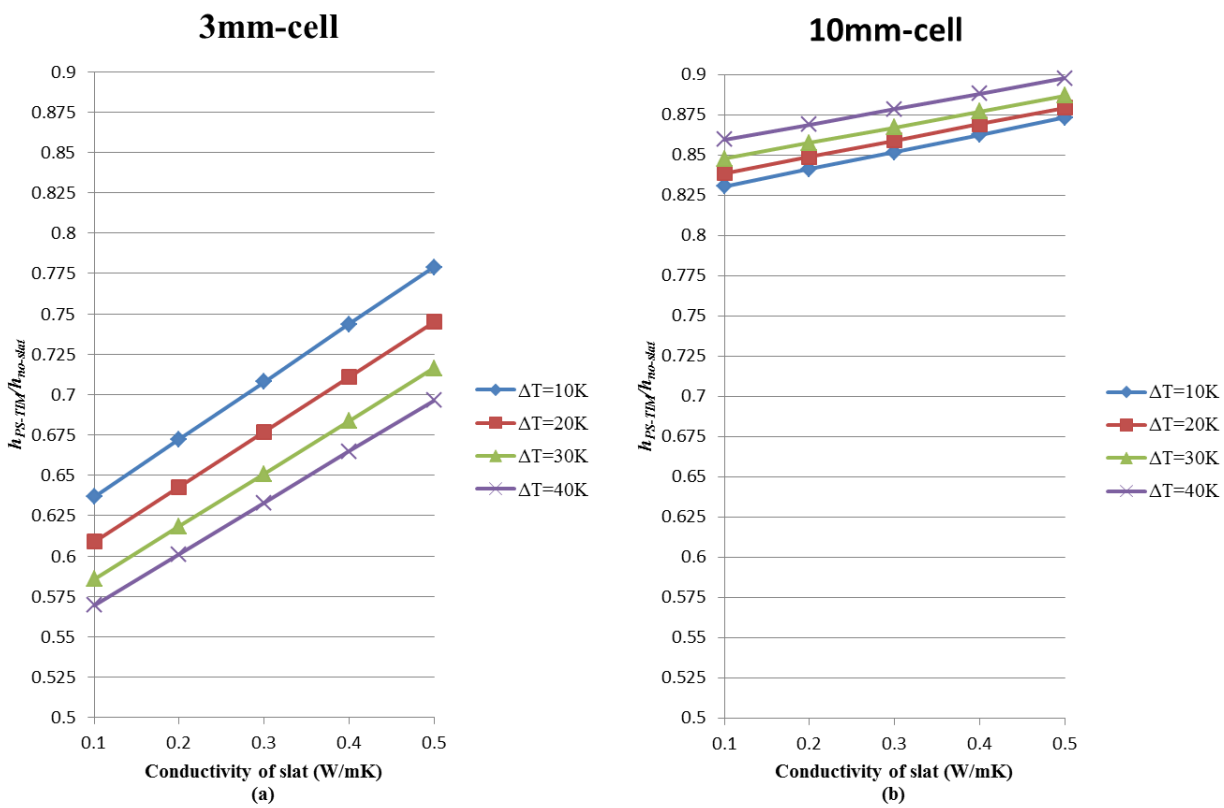

6

7 Fig. 10. Thermal conductance ratio ( $\left.\mathrm{h}_{\mathrm{PS}-\mathrm{TIM}} / \mathrm{h}_{\text {no-slat }}\right)$ for different slat conductivities $(\mathrm{W} / \mathrm{mK})$ at various glazing pane temperature differences

The effect of the material conductivity of the PS-TIM structure on the thermal conductance is illustrated in Fig. 10. When the slat thermal conductivity increases from 0.1 to

$110.5 \mathrm{~W} / \mathrm{mK}$ (while maintaining $\mathrm{D}_{\mathrm{s}}=0.1 \mathrm{~mm}$ and $\varepsilon=0.65$ ), the thermal conductance of the glazing system increases for both the $3 \mathrm{~mm}$-cell and $10 \mathrm{~mm}$-cell PS-TIMs. The slat conductivity has a more significant influence on the 3mm-cell PS-TIM because it has higher numbers of slats and hence a greater total area of structural bridging as compared with the

$1510 \mathrm{~mm}$-cell PS-TIM. For example, when the temperature difference between the two panes of 16 glass is $10 \mathrm{~K}$, increasing the conductivity of the slats from $0.1 \mathrm{~W} / \mathrm{mK}$ to $0.5 \mathrm{~W} / \mathrm{mK}$ increases 17 the thermal conductance of the $3 \mathrm{~mm}$-cell PS-TIM from approximately $63.5 \%$ to $78 \%$ 
1 (relative to a standard double glazing unit). For the $10 \mathrm{~mm}$-cell PS-TIM at the same

2 temperature difference, the thermal conductance only increases from $83 \%$ to $87.5 \%$.

4 i.e. thermal conductance ratio increases with increasing thermal conductivity, however, the

5 combined influence of conduction, convection and radiation that is illustrated in Fig. 9 is

6 maintained. The overall benefits offered by the 3mm-cell PS-TIM through reduced radiative

7 and convective conductance more than outweigh these increases in conduction, so that at any

8 given value of conductivity, the conductance ratio decreases with increasing temperature

9 difference. By contrast, the 10mm-cell PS-TIM, where increasing temperature difference 10 drives stronger convection, exhibits an increasing conductance ratio, ie at any given value of 11 conductivity, the conductance ratio increases with increasing temperature difference.

12

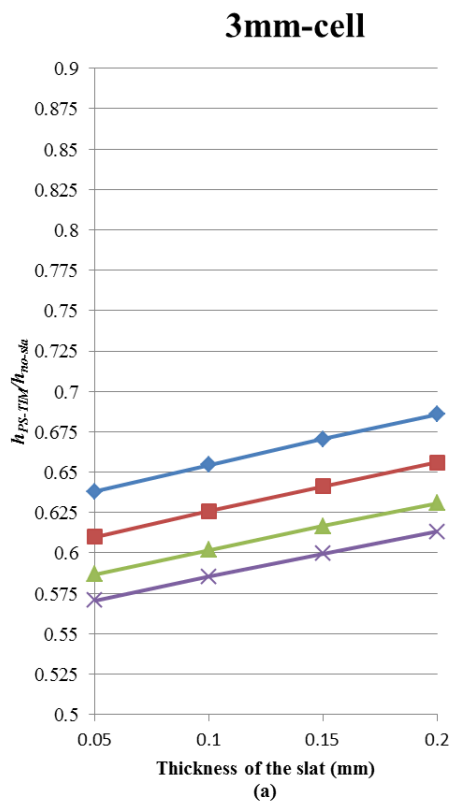

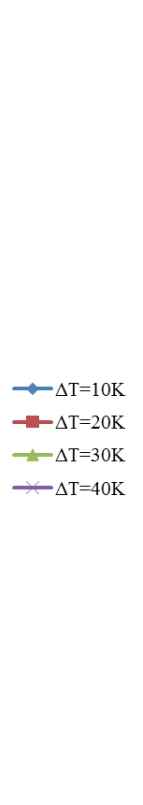

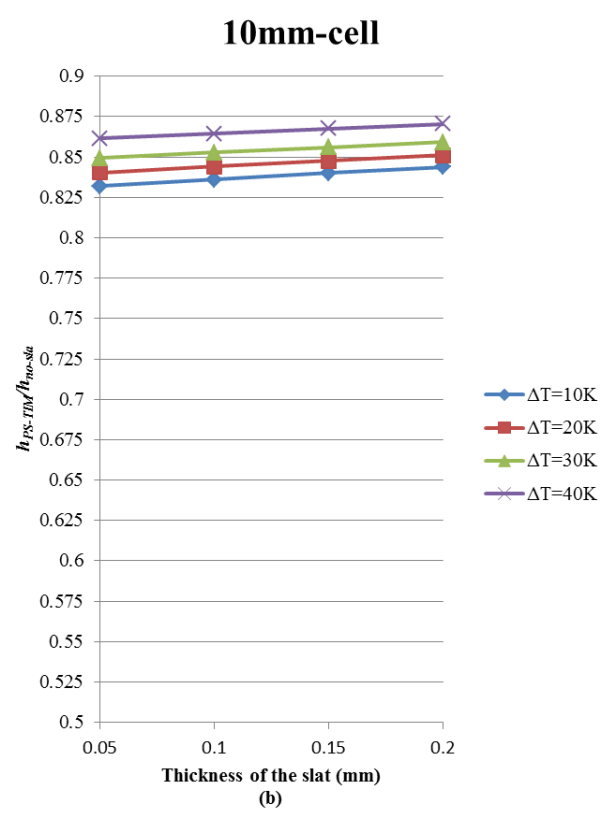

13 Fig. 11. Thermal conductance ratio ( $\left.\mathrm{h}_{\mathrm{PS}-\mathrm{TIM}} / \mathrm{h}_{\text {no-slat }}\right)$ for different slat thickness $(\mathrm{mm})$ at various glazing pane 14 temperature differences

15 Fig. 11. shows the influence of slat thickness, $D_{s}$, on of thermal conductance (while maintaining $\lambda_{\mathrm{s}}=0.15 \mathrm{~W} / \mathrm{mK}$ and $\varepsilon=0.65$, again measured relative to a standard double glazing unit. As might be expected, given the relationship between conductance, conductivity 
1 and the cross sectional area of any element through which conduction is occurring, the

2 general pattern of behaviour illustrated in Fig. 11 echoes that in Fig. 10. The effect of

3 increasing the slat thickness is, however, less pronounced than that of increasing its

4 conductivity because in addition to increasing heat flux conducted across the cavity, it

5 simultaneously reduces the height of the air cells in the PS-TIM. This in turn reduces heat

6 transfer between the two glazing surfaces taking place by radiation and convection, reducing

$7 \quad$ the slope of the curves in Fig. 11.
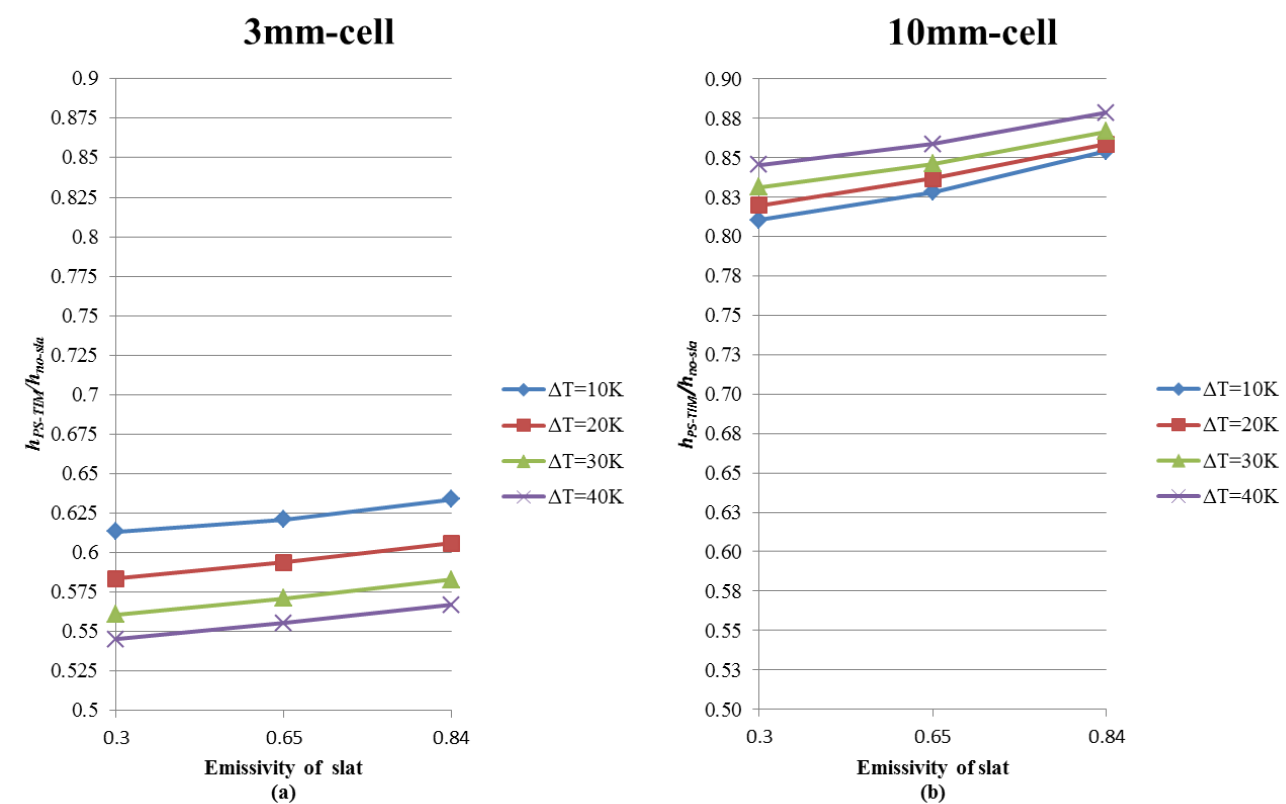

9 Fig. 12. Thermal conductance ratio ( $\left.\mathrm{h}_{\mathrm{PS}-\mathrm{TIM}} / \mathrm{h}_{\text {no-slat }}\right)$ at different slat emissivity at various glazing pane temperature differences

The predicted variation of total thermal conductance ratio for three values of slat emissivity $(\varepsilon=0.3,0.65$ and 0.84$)$ while maintaining $\mathrm{D}_{\mathrm{s}}=0.1 \mathrm{~mm}$ and $\lambda_{\mathrm{s}}=0.15 \mathrm{~W} / \mathrm{mK}$, is shown in Fig 12. It can be seen that with increasing emissivity, the thermal conductance ratio for both the $3 \mathrm{~mm}$ and $10 \mathrm{~mm}$-cell PS-TIMs increases. The effect is relatively weak however.

15 For example, when the emissivity of the slat is increased from 0.3 to 0.84 under a 16 temperature difference of $40 \mathrm{~K}$, the thermal conductance ratio increases by only $2 \%$ for a $173 \mathrm{~mm}$-cell structure and $3.5 \%$ for a $10 \mathrm{~mm}$-cell structure. Given the strength of the radiative 
1 path indicated in Fig. 8, this suggests that heat radiated and re-radiated from the slats is

2 secondary to heat directly radiated across the cavity from one glazing pane to the other.

4 thermal conductance of double glazed windows containing PS-TIM held at a constant

5 temperature difference: this effect is more significant on PS-TIMs with 'small' cells.

6 Decreasing slat emissivity has weak but beneficial effect, reducing the thermal conductance

7 of double glazed windows containing a PS-TIM structure.

\section{$8 \quad 4.5$ A comparison of $U$-value and light transmittance of PS-TIM}

9 The overall heat transfer of the glazing system under standard boundary conditions EN 673

10 [34] (temperature difference of $15 \mathrm{~K}$ between two glazing panes, average glazing pane 11 temperature of $\left.10^{\circ} \mathrm{C}(283 \mathrm{~K})\right)$ was simulated and the results are discussed in this section. Fig.

1213 illustrates the total thermal resistance $\left(\frac{1}{\mathrm{U}}\right)$, which is the sum of the thermal resistance 13 between two glass panes $\left(\frac{1}{h}\right)$, the thermal resistance of the glass panes $\left(\frac{2 \mathrm{~d}}{\lambda_{\mathrm{g}}}\right)$ and the external 14 and internal surface thermal resistances $\left(\frac{1}{h_{e}}\right.$ and $\left.\frac{1}{h_{i}}\right)$ (see equations (11)-(12)). The U-values of 15 double glazing with and without PS-TIM structures are shown in Table 2.

16 A ray tracing technique was used to study the optical performance of the glazing system. The 17 predicted transmittances of the PS-TIM systems at solar incidence angles between $5^{\circ}$ to $85^{\circ}$ 18 predicted at $10^{\circ}$ intervals are shown in Fig. 14. 


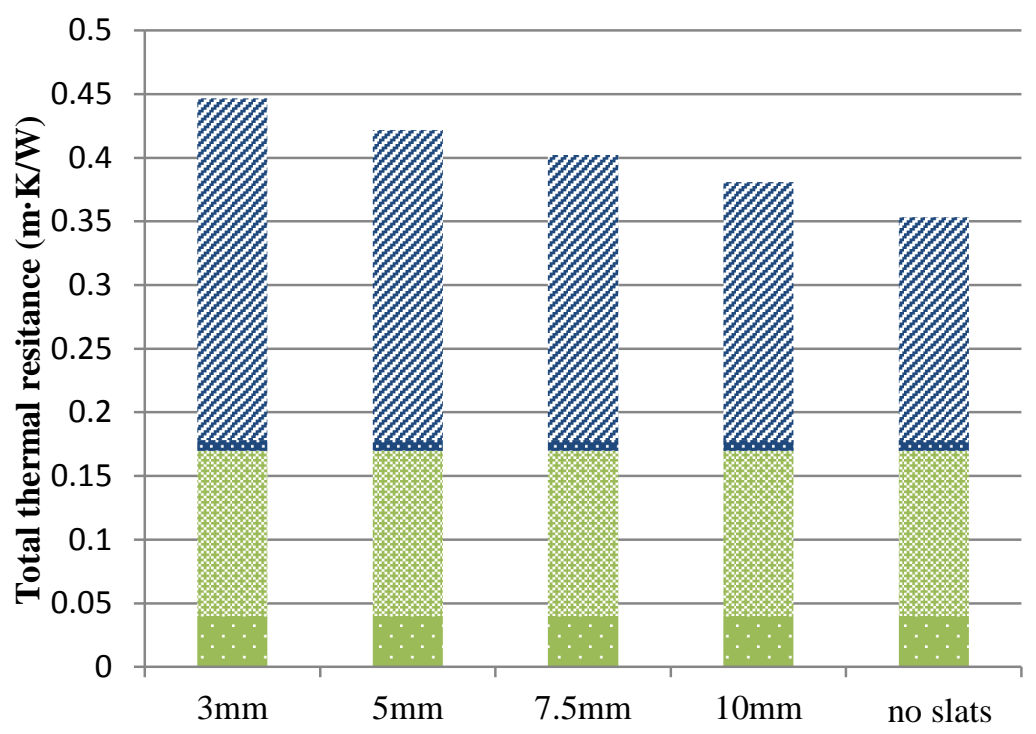

\% Thermal resistance between two glass panes

Glass panes thermal resistance

Internal surfaces thermal resistance

External surfaces thermal resistance

7

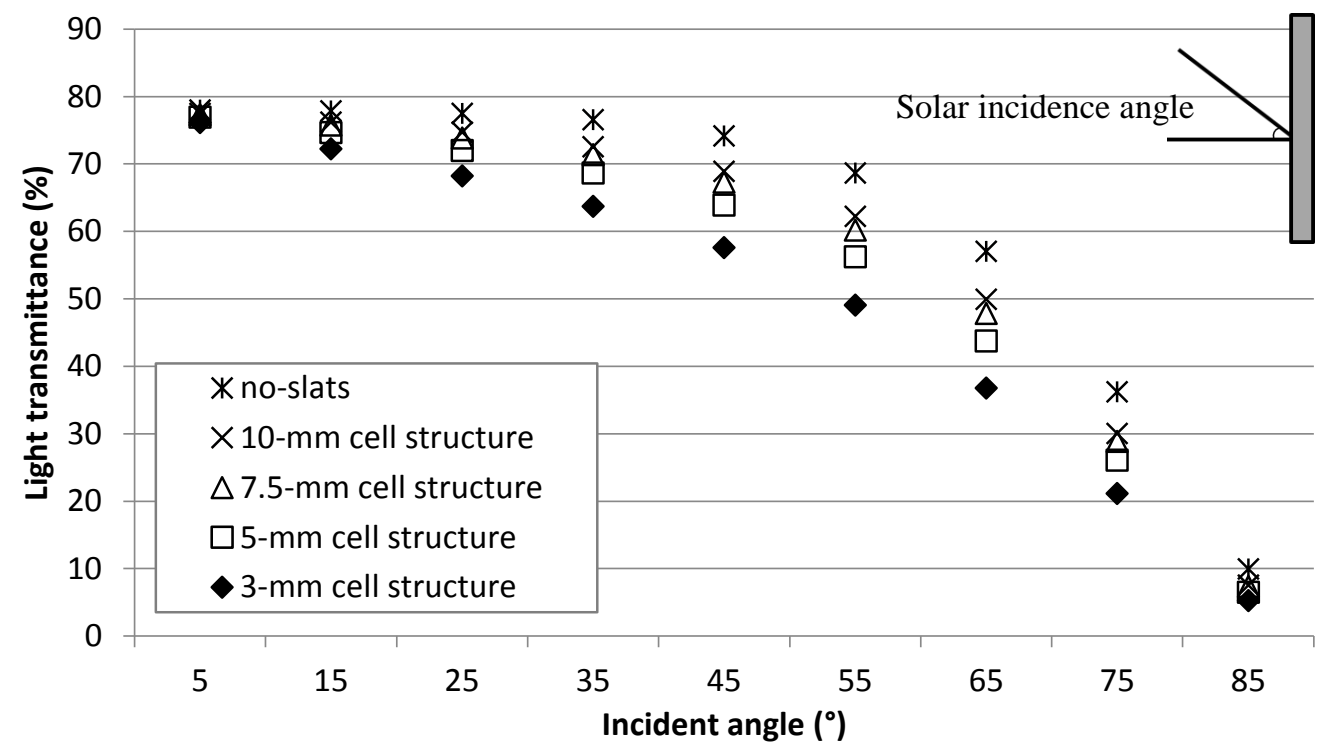

Fig. 14. Light transmittance at different incidence angles for a double glazed window containing PS-TIM structures

From Figs. 13 and 14, and Table 2, it can be seen that because the surface thermal

12 resistances and glass pane thermal resistance are common to all of the windows studied, the

13 change in predicted performance is due solely to the effect of the PS-TIM. Adding PS-TIM 
1 and reducing the slat interval distance from $10 \mathrm{~mm}$ to $3 \mathrm{~mm}$ leads to a gradual increase of

2 thermal resistance between two glazing panes and hence a reduction of the U-value. The

3 thermal resistance between two glazing panes only contributes to $49.5 \%$ of the total thermal

4 resistance in the standard double glazing unit, and the contribution has been increased to $60 \%$

5 by adding $3 \mathrm{~mm}$-cell structure in the air cavity. This is reflected in a $21 \%$ reduction of the U-

6 value.

7

The PS-TIM is less beneficial in relation to light transmission. Reducing the slat interval distance from $10 \mathrm{~mm}$ to $3 \mathrm{~mm}$ results in a $1.6 \%-20.3 \%$ decrease in light transmittance at incidence angles between $15^{\circ}-85^{\circ}$. The $7.5 \mathrm{~mm}$ cells and $10 \mathrm{~mm}$ cells have a better light transmittance than the $3 \mathrm{~mm}$ and $5 \mathrm{~mm}$ structures. When compared with the double glazing without PS-TIM, the $7.5 \mathrm{~mm}$ and $10 \mathrm{~mm}$ cells only have $1.6 \%-9.2 \%$ reduction of light transmittance for solar incidence angle between $15^{\circ}-85^{\circ}$, and reduce the U-value by $10 \%$ and $5 \%$, respectively. These systems are able to provide useful daylight transmission into room for both lighting and passive heating requirements in the winter time (where the solar incidence angle is low). Although $5 \mathrm{~mm}$ and $3 \mathrm{~mm}$ cells structure offer better thermal resistance, the light transmittances decrease by over $10 \%$ and $27 \%$ respectively compared with $7.5 \mathrm{~mm}$ cells.

The study presented here is limited, and interpreting how a balance is made between thermal and light related properties when designing a façade is complex, depending on climate, prevailing sky conditions, selection of lighting technology, building function, etc. As a general observation, PS-TIM offers improved thermal performance and maintains access to daylight (albeit at reduced levels), but has the potential to interrupt view. As part of an overarching glazing strategy, PS-TIM may therefore be usefully used to maintain the external appearance of a glazed façade and admit daylight above and below any regions of a façade 
1 reserved for maintaining view out of or into a building, where conventional glazing would be

2 more appropriate.

\section{5. CONCLUSIONS}

4

5 Parallel Slat TIM (PS-TIM) structures sandwiched between the panes of a double glazed

6 window unit has been conducted. The following conclusions can be drawn:

7 1) For windows, when the aspect ratio of a cell (whose geometry is defined by the ratio of

8 the PS-TIM slat spacing to the separation between double glazing panes) is less than 0.35 ,

9 free convection is fully suppressed and is independent of the temperature difference between 10 the two surface panes;

2) In practice, selecting a suitable interval distance for the parallel slats in the air cavity such that the Nusselt number is less than 1.2 can provide good reduction of the convective heat transfer coefficient;

3) The results of a convection, conduction and radiation model show that a double glazed unit containing PS-TIM with a $3 \mathrm{~mm}$-cell structure can offer a $35 \%-46 \%$ reduction in thermal conductance as compared with an identical double glazing unit in the absence of PS-TIM. The equivalent performance for PS-TIM with a $10 \mathrm{~mm}$-cell structure is a $16 \%-18 \%$ reduction in conductance. The slat conductivity and thickness have a significant influence on overall thermal conductance when the temperature difference between the glazing panes is small;

4) The combined influence of light transmittance and U-value has been touched upon and offers some tentative suggestions as to how architects and engineers might apply PS-TIM to windows or glazed facades. 
This work was supported by the Faculty of Engineering, University of Nottingham

and the China Scholarship Council through a joint PhD studentship awarded to Yanyi Sun.

\section{REFERENCES}

[1] Mangkuto RA, Wang S, Meerbeek BW, Aries MBC, Loenen EJv. Lighting performance and electrical energy consumption of a virtual window prototype. Applied Energy. 2014;135:261-73.

[2] Wong IL, Eames PC, Perera RS. A review of transparent insulation systems and the evaluation of payback period for building applications. Solar Energy. 2007;81:1058-71. [3] Sun Y, Wu Y, Wilson R, Lu S. Experimental measurement and numerical simulation of the thermal performance of a double glazing system with an interstitial Venetian blind. Building and Environment. 2016 103:111-22.

[4] Berardi U. The development of a monolithic aerogel glazed window for an energy retrofitting project. Applied Energy. 2015;154:603-15.

[5] Jensen KI, Schultz JM, Kristiansen FH. Development of windows based on highly insulating aerogel glazings. Journal of Non-Crystalline Solids. 2004;350:351-7.

[6] Gao T, Jelle BP, Ihara T, Gustavsen A. Insulating glazing units with silica aerogel granules: The impact of particle size. Applied Energy. 2014;128:27-34.

[7] Buratti C, Moretti E. Experimental performance evaluation of aerogel glazing systems. Applied Energy. 2012;97:430-7.

[8] Arulanantham M, Singh TP, Kaushika ND. Convective heat transfer across transparent honeycomb insulation materials. Energy Convers Mgmt 1994;35:111-6.

[9] Kaushika ND, Padmapriya P, Arulanantham M, Sharma PK. Transparent insulation characteristics of honeycomb and slat arrays Energy and Buildings. 1994;19:1037-41. [10] Kaushika ND, Kumar P. Convective effects in air layers bound by cellular honeycomb arrays. Journal of Scientific \& Industrial Research. 2005;64:602-12.

[11] Arulanantham M, Kaushika ND. Coupled radiative and conductive thermal transfers across transparent honeycomb insulation materials. Applied Thermal Engineering. 1996;16:209-12.

[12] Suehrcke H, Däldehög D, Harris JA, Lowe RW. Heat transfer across corrugated sheets and honeycomb transparent insulation. Solar Energy. 2004;76:351-8.

[13] He W, Ji J, Wang G, Yi H, Pei G, Dong J. Experimental and theoretic study of heat transfer and transmittivity of shutter-type transparent honeycomb structure.

Taiyangneng Xuebao/Acta Energiae Solaris Sinica,. 2003;24:290-4.

[14] Lien AG, Hestnes AG, Aschehoug $O$. The use of transparent insulation in low energy dwellings in cold climates. Solar Energy. 1997;59:27-35.

[15] Wong IL, Eames PC, Perera RS. Energy simulations of a transparent - insulated office façade retrofit in London, UK. Smart and Sustainable Built Environment. 2012;1:253-76.

[16] N.Y.T. Huang, J.L.Wright, M.R. Collins. Thermal resistance of a window with an enclosed Venetian blind: guarded heater plate measurements. ASHRAE Transactions. 2006;112:13-21.

[17] Naylor D, Collins M. Evaluation of an Approximate Method for Predicting The Uvalue of a Window with a between-Panes Blind. Numerical Heat Transfer, Part A:

Applications. 2005;47:233-50.

[18] Wright JL, Jin H, Hollands KGT, Naylor D. Flow visualization of natural convection in a tall, air-filled vertical cavity. International Journal of Heat and Mass Transfer. 2006;49:889-904.

[19] Naylor D, Lai BY. Experimental Study of Natural Convection in a Window with a Between-Panes Venetian Blind. Experimental Heat Transfer. 2007;20:1-17. 
[20] Almeida F, Naylor D. Experimental study of free convection in a window with a heated between-panes blind. Energy and Buildings. 2011;43:2647-55.

[21] Collins M, Tasnim S, Wright J. Numerical analysis of convective heat transfer in fenestration with between-the-glass louvered shades. Building and Environment. 2009; 44:2185-92.

[22] Dalal R, D. Naylor, Roeleveld D. A CFD study of convection in a double glazed window with an enclosed pleated blind. Energy and Buildings. 2009;41:1256-62. [23] Avedissian T, Naylor D. Free convective heat transfer in an enclosure with an internal louvered blind International Journal of Heat and Mass Transfer. 2008;51:283-93. [24] Giorgi LD, Bertola V, Cafaro E. Thermal convection in double glazed windows with structured gap. Energy and Buildings. 2011;43:2034-8.

[25] Gomes MG, Santos AJ, Rodrigues AM. Solar and visible optical properties of glazing systems with venetian blinds: Numerical, experimental and blind control study. Building and Environment. 2014;71:47-59.

[26] Andersen M, Rubin M, Scartezzini J-L. Comparison between ray-tracing simulations and bi-directional transmission measurements on prismatic glazing. Solar Energy. 2003;74:157-73.

[27] Andersen M, Rubin M, Powles R, Scartezzini JL. Bi-directional transmission properties of Venetian blinds: experimental assessment compared to ray-tracing calculations. Solar Energy. 2005;78:187-98.

[28] Wang Y, Chen Y, Guo X, He W, Gao L. Development of a Solar Control Method of the Venetian Blinds. Procedia Engineering. 2015;121:1186-92.

[29] Maria Konstantoglou, Jacob C. Jonsson, Lee E. Simulating Complex Window Systems using BSDF Data. PLEA2009-26th Conference on Passive and Low Energy Architecture. Quebec City, Canada2009.

[30] Tzempelikos A. The impact of venetian blind geometry and tilt angle on view, direct light transmission and interior illuminance. Solar Energy. 2008;82:1172-91.

[31] Konstantzos I, Chan Y-C, Seibold JC, Tzempelikos A, Proctor RW, Protzman JB. View clarity index: A new metric to evaluate clarity of view through window shades. Building and Environment. 2015;90:206-14.

[32] Duffie JA, Beckman WA. Solar engineering of thermal processes. 3rd ed. Hoboken, N.J. : Wiley; 2006.

[33] CIBSE. Guide A - Environmental Design. 7 ed. London: CIBSE Publications; 2006. [34] EN 673 Glass in building-- Determination of thermal transmittance (U value) Calculation method. European standard2011

[35] Lee Y, Korpela SA. Multicellular natural convection in a vertical slot. J Fluid mech. $1983 ; 126$ 91-121. 